\title{
The effect of Agaricus brasiliensis extract supplementation on honey bee colonies
}

\author{
JEVROSIMA STEVANOVIC ${ }^{1}$, ZORAN STANIMIROVIC ${ }^{1}$, PREDRAG SIMEUNOVIC ${ }^{1}$, NADA \\ LAKIC ${ }^{2}$, IVICA RADOVIC ${ }^{3}$, MARINA SOKOVIC ${ }^{4}$ and LEO J.L.D. VAN GRIENSVEN ${ }^{5}$ \\ ${ }^{1}$ Department of Biology, Faculty of Veterinary Medicine, University of Belgrade, Bul. Oslobodjenja 18, 11000 Belgrade, Serbia \\ ${ }^{2}$ Department of Statistics, Faculty of Agriculture, University of Belgrade, Nemanjina 6, 11081 Belgrade-Zemun, Serbia \\ ${ }^{3}$ Civil Protection and Environment Protection Studies Department, Faculty of Security \\ Studies, University of Belgrade, Gospodara Vucica 50, 11000 Belgrade, Serbia \\ ${ }^{4}$ Department of Plant Physiology, Institute for Biological Research "Sinisa Stankovic", \\ University of Belgrade, Bulevar Despota Stefana 142, 11000 Belgrade, Serbia \\ ${ }^{5}$ Plant Research International, Wageningen University and Research, Bornsesteeg 1, 6708 PD Wageningen, The Netherlands
}

Manuscript received on March 6, 2015; accepted for publication on September 4, 2015

\begin{abstract}
This study was done to discover any beneficial effect of a medicinal mushroom Agaricus brasiliensis extract on the honey bee. Firstly, a laboratory experiment was conducted on 640 bees reared in 32 singleuse plastic rearing cups. A. brasiliensis extract proved safe in all doses tested $(50,100$ and $150 \mathrm{mg} / \mathrm{kg} /$ day) irrespective of feeding mode (sugar syrup or candy). Secondly, a three-year field experiment was conducted on 26 colonies treated with a single dose of A. brasiliensis extract ( $100 \mathrm{mg} / \mathrm{kg} /$ day) added to syrup. Each year the colonies were treated once in autumn and twice in spring. The treatments significantly increased colony strength parameters: brood rearing improvement and adult population growth were noticed more often than the increase in honey production and pollen reserves. These positive effects were mainly observed in April. In conclusion, A. brasiliensis extract is safe for the bees and helps maintaining strong colonies, especially in spring.
\end{abstract}

Key words: Apis mellifera, colony strength, medicinal mushroom 'Cogumelo do Sol', natural-based supplement.

\section{INTRODUCTION}

Honey bees Apis mellifera L. (Hymenoptera: Apidae) play a great role in pollination of both crops and wild flora. As wild non-honeybee pollinators are in constant decline, the importance of managed honey bees is inestimable for sustainable agriculture and conservation of natural plant biodiversity (De

Correspondence to: Jevrosima Stevanovic

E-mail: rocky@vet.bg.ac.rs la Rúa et al. 2009, Moritz et al. 2010). Besides, honey and other hive products (propolis, royal jelly and bee venom) display a variety of positive nutritional and/or health effects in humans (ViudaMartos et al. 2008, Alvarez-Suarez et al. 2010).

Unfortunately, dramatic losses of managed honey bee colonies have been reported in Europe and North America over the past decade (vanEngelsdorp et al. 2009, Genersch et al. 2010, Neumann and Carreck 2010, Potts et al. 2010, 
Ellis et al. 2010). As no single explanation for the extensive colony losses has been identified, it is concluded that many biological and environmental stressors, acting alone or in combination, can lead to premature colony mortality (vanEngelsdorp et al. 2009, Genersch 2010, Le Conte et al. 2010). Along with bee diseases, many problems in beekeeping are caused by chemicals used against honey bee pathogens, whose appliance is accompanied by side effects on bees and brood (Pettis et al. 2004a, 2004b, Loucif-Ayad et al. 2008), contamination of bee products (Bogdanov 2006) and health risk to beekeepers and bee product consumers (Stanimirovic et al. 2005, 2007, Stevanovic et al. 2008, Radakovic et al. 2013). Therefore, it would be benefitial if some harmless naturalbased supplements could provide maintaining healthy and strong honey bee colonies and help in prevention of their mortality. For that reason we decided to investigate the effect of extract of the medicinal mushroom, Agaricus brasiliensis Wasser et al., syn. Agaricus blazei Murrill ss. Heinemann (Wasser et al. 2002) on honey bees and to evaluate the potential of its use in beekeeping.

Agaricus brasiliensis (Basidiomycetes) is an edible mushroom of Brazilian origin, popularly known as 'Sun Mushroom' ('Cogumelo do Sol' in Portuguese) in Brazil and 'Himematsutake' in Japan. It has been used in traditional medicine as a healthy food supplement and against a variety of diseases, including cancer, diabetes, hyperlipidaemia, arteriosclerosis and chronic hepatitis (Wasser and Weis 1999). Numerous healthpromoting effects of $A$. brasiliensis have been scientifically proved (Wei and Van Griensven 2008, Hetland et al. 2008, Kozarski et al. 2011, Roupas et al. 2012). Antigenotoxic, anticarcinogenic, antimutagenic and antitumor activities have been described (Guterres et al. 2005, Mantovani et al. 2008, Kim et al. 2009, Ishii et al. 2011) and a wide range of immunomodulatory properties (Johnson et al. 2009, Ishii et al. 2011, Kozarski et al. 2011,
Smiderle et al. 2011, 2013). All these beneficial effects of $A$. brasiliensis were demonstrated on mammals or mammalian cells in vitro and with the aim of promoting human health. However, no study has ever been undertaken to evaluate the effect on maintaining health of social insects. The only research on insects was that of Savić et al. (2011) who used Drosophila melanogaster in vivo assay to evaluate the antigenotoxic and/or protective effects of $A$. brasiliensis against experimentally induced mutations. Thus, this study was attempted to investigate if its extract supplementation exerts beneficial effects on honey bees, firstly by evaluating the its safety in laboratory conditions, and secondly by monitoring the influence of $A$. brasiliensis extract on colony strength parameters (brood areas, adult bee population, honey and pollen reserves) in field experiment during three successive years.

\section{MATERIALS AND METHODS}

\section{BEES}

The research was conducted on the European honey bee (Apis mellifera) from the experimental apiary belonging to the Faculty of Veterinary Medicine of the University of Belgrade. The apiary is situated in the close vicinity of the laboratory, which facilitated the performance of the experiment.

\section{MUSHROOM EXTRACT}

In this study Agaricus brasiliensis strain M7700 (Mycelia bvba, Nevele, Belgium) was used. Hotwater extract was made from fresh fruiting bodies, dried in vacuo, ground to fine powder and stored until use. Mushroom cultivation and extract preparation were described previously (Wei and Van Griensven 2008, Savić et al. 2011). GC-MS and NMR spectroscopy (Smiderle et al. 2011, 2013) showed that the extract was rich in polysaccharides $(45.9 \mathrm{~g} / 100 \mathrm{~g})$, mostly glucans $(40.1 \mathrm{~g} / 100 \mathrm{~g})$ : $\alpha$-glucans $17.3 \mathrm{~g} / 100 \mathrm{~g}$ and $\beta$-glucans $22.8 \mathrm{~g} / 100 \mathrm{~g}$ 
(Kozarski et al. 2011). In addition, phenols ( $1 \mathrm{~g} / 100$ g) and proteins $(4.7 \mathrm{~g} / 100 \mathrm{~g})$ were also detected (Kozarski et al. 2014).

SAFETY OF A. brasiliensis EXTRACT - LABORATORY EXPERIMENT

The safety test was performed on newly emerged adult worker bees maintained in single-use plastic rearing cups $(400 \mathrm{~mL})$, as recommended by Evans et al. (2009). To obtain newly emerged bees, the combs with sealed cells close to bee emergence were brought to the laboratory and incubated in darkness at $34^{\circ} \mathrm{C}$ and $65 \% \mathrm{RH}$. The emerged bees were manually collected from the combs and confined to single-use rearing cups. Twenty randomly chosen bees were put in each cup and kept at $30^{\circ} \mathrm{C}, 50 \% \mathrm{RH}$, in darkness (Fries 1988).

In the laboratory experiment 640 bees in 32 cups were used: there were 4 experimental groups ( 3 treated +1 control), 2 feeding modes (syrup and candy) and 4 replicates of each group. Three doses of $A$. brasiliensis extract were tested: 50, 100 and $150 \mathrm{mg} / \mathrm{kg} /$ day, the median one $(100 \mathrm{mg} / \mathrm{kg} /$ day $)$ corresponding to commonly tested doses of the substance in other in vivo test systems (Kim et al. 2009). Thus, 20 bees weighing $2 \mathrm{~g}$, placed in each rearing cup, were to receive $0.2 \mathrm{mg}$ of extract per day. As daily consumption rate per bee is $50 \mathrm{mg}$ (Maistrello et al. 2008), 20 bees in a cup consume $1000 \mathrm{mg}(1 \mathrm{~g})$ of food each day. Thus, $0.2 \mathrm{mg}$ of $A$. brasiliensis extract mixed in $1 \mathrm{~g}$ of candy (or $1 \mathrm{ml}$ of syrup) provided the required daily dose per cup. The control bees were fed with untreated syrup or candy prepared as in Costa et al. (2010). The syrup was administered as described previously (Costa et al. 2010), and candy was divided into smaller pieces placed close to the edge of the rearing cup. This innovation enabled greater candy surface area available to the bees and easy addition of water (by syringe) when needed.

\section{FIELD EXPERIMENT}

Honey bee colonies for the field experiment were maintained in standard European Langstroth (LR) hives. The hive experiment was conducted during three successive years 2010/2011, 2011/2012 and $2012 / 2013$ with different weather status. Winters 2010/2011 and 2012/2013 were temperate, with temperatures and precipitation within the limits of average in the last decades (RHMZ 2013). However, winter 2011/2012 was specific, as December 2011 and January 2012 were mild, with average temperatures higher than usual, whilst in February 2012 there was an extremely cold period (the mean monthly temperature was $6.6^{\circ} \mathrm{C}$ below the average), with as low as $-27^{\circ} \mathrm{C}$ recorded continually during a whole week (RHMZ 2013).

During the experimental period, colonies were regularly checked for both bee and brood pathology by a veterinary specialist, following the instructions of the "Office International des Epizooties" (OIE 2013). Varroa destructor infestation was controlled twice a year with taufluvalinat (Varotom ${ }^{\circledR}$, Evrotom, Ruma, Serbia). In June 2010, all experimental colonies (both treated and controls) received newly-emerged naturally mated sister queens originated from a mother queen of known C2d haplotype (Kozmus et al. 2007, Muñoz et al. 2012). Queens had been marked to facilitate their monitoring and to ensure that all experimental colonies were headed by the queens of the same age (one-year-old queens in 2010/2011, two-year-old in 2011/2012 and threeyear-old queens in 2012/2013).

Each autumn 26 colonies of uniform strength were set up for the experiment (22 treated and 4 controls). As the trial was always carried out in the period from September to April, the colonies were equalized in autumn (prior to wintering). Equalization was done in regard to adult bee population and food resources (amounts of honey and pollen stored) since very small amounts of 
brood were present in each hive. Spring colony assessment included the measurement of five strength parameters: open brood area (OB) sealed brood area (SB), adult bee population $(\mathrm{AB})$, honey reserves (HR) and pollen reserves (PR). Measurements were performed using the methodology described in DeGrandi-Hoffman et al. (2008), recently included in standard methods for estimating strength parameters of Apis mellifera colonies (Delaplane et al. 2013). Briefly, measurements were made using a transparent grid with $5 \times 5 \mathrm{~cm}$ squares. The grid was laid over each side of every frame and the number of squares covered with brood (open and sealed, separately), stored food (pollen and honey, separately) or adult bees was counted and recorded. For each parameter monitored, measurements of all frames were summed up for the whole colony. The estimated values for $\mathrm{OB}, \mathrm{SB}, \mathrm{SH}$ and $\mathrm{SP}$ are expressed in $\mathrm{cm}^{2}$, while the $A B$ is expressed in number of bees, calculated from the area of comb occupied by adult bees given the appropriate density of 1.25 bees / $\mathrm{cm}^{2}$ on LR frame type (Delaplane et al. 2013).

Having considered the results of the laboratory experiment, the colonies were treated with a dose of $100 \mathrm{mg} / \mathrm{kg} /$ day: a bee colony in the hive of 3 $\mathrm{kg}$ weight, were given $300 \mathrm{mg}$ of $A$. brasiliensis extract each day. In the presence of already stored honey the bees intake of the treated syrup during 22 days should be $300 \mathrm{mg}$ x $22=6.6$ g extract per hive per treatment.

The treated colonies received the extract three times a year: once in autumn and two times in spring. Autumn treatment (on the day A) was applied immediately after equalization of hives. The first spring treatment (day S1) was performed during the first spring inspection of the hives (first half of March), and the second (day S2) 22 days later. In the treatment of colonies only syrup feeding was used, as it was prefered to candy in both the laboratory (Costa et al. 2010 and the results of this study) and field experiments (Higes et al. 2011). For each hive $6.6 \mathrm{~g}$ of $A$. brasiliensis extract was mixed in $1 \mathrm{~L}$ of sugar syrup (50\% sugar, $40 \%$ water and and $10 \%$ honey from experimental colonies) and applied three consecutive days $(330 \mathrm{ml}$ per day). The control colonies were fed with plain syrup.

The effect of the treatments was assessed by measuring the five strength parameters $(\mathrm{OB}, \mathrm{SB}$, $\mathrm{AB}, \mathrm{HR}$ and PR) on three monitoring days: on the day of first spring treatment (day S1), 22 days later (second spring treatment, day S2), and finally, 22 days after that, at the end of April, before the main Acacia honey flow (day S3)

\section{STATISTICAL ANALYSIS}

Statistical analysis of the results was based on nonparametric tests since the data were not homogeneous $\left(c_{v}>30 \%\right)$, not normally distributed $(\mathrm{p}<0.05$ for Shapiro-Wilk's W test) and variances of samples were not homogeneous $(p<0.05$ for Levene's test).

To evaluate the safety of the test substance in laboratory experiment, the survival of bees was monitored. The number of surviving bees in each rearing cup was recorded on days 7, 14 and 21 . The Kruskal-Wallis test (Marques de Sá 2007) was applied to test the differences in survival in each group on days 7, 14 and 21. Mann-Whitney U test (Marques de Sá 2007) was used to test the differences in survival between groups fed with syrup and candy.

In field experiment, the Mann-Whitney U test was applied to evaluate the effect of the test substance (A. brasiliensis extract) on the colony strength parameters. The treated colonies were compared to the controls within each study year and on each monitoring day (S1, S2 and S3). Moreover, the influence of the year on monitored colony strength parameters was evaluated in both treated and control colonies on each monitoring day (S1, S2 and S3). Kruskal-Wallis test was applied to test the differences in colony strength parameters in the 
whole three-year period, while Mann-Whitney U test was used for paired comparisons between years.

\section{RESULTS}

\section{SAFETY OF A. brasiliensis EXTRACT}

The results of Kruskal-Wallis test revealed no significant $(\mathrm{p}>0.05)$ differences in the survival of bees among groups (treated with A. brasiliensis extract and control) in both feeding modes (syrup and candy). These results indicated that all tested doses were safe for and may be applied to bees in the field experiment.

The highest number of rearing cups without bee mortality was in the group fed with the $A$. brasiliensis extract in the dose of $100 \mathrm{mg} / \mathrm{kg} /$ day in both feeding modes, syrup (50.00\%) and candy (62.50\%). Thus, this dose was used in the field experiment.

The results of Mann-Whitney U test revealed no significant $(p>0.05)$ differences in the survival of bees between groups fed with syrup or candy (Table I), meaning that the survival did not depend on feeding mode. However, in laboratory conditions syrup feeding proved better than candy as it was always completely consumed. By contrast, candy desiccated quickly and became hard so the bees were unable to intake the complete dose of the test substance when mixed in candy. Thus, only syrup feeding mode was applied in the field experiment.

\section{FIELD EXPERIMENT}

The effect of A. brasiliensis extract on strength parameters of honey bee colonies

Since experimental data did not meet the conditions for the application of parametric test, comparison of average values of strength parameters between treated and control honey bee colonies was performed by Mann-Whitney U test (Table II).

TABLE I

The differences in survival of bees between groups fed with syrup and candy (Mann-Whitney $U$ test).

\begin{tabular}{|c|c|c|c|c|c|c|}
\hline \multirow{2}{*}{$\begin{array}{c}\text { AbM extract dose } \\
\mathrm{mg} / \mathrm{kg} / \mathrm{day}\end{array}$} & \multicolumn{2}{|c|}{ Until $7^{\text {th }}$ day } & \multicolumn{2}{|c|}{ Until 14 $^{\text {th }}$ day } & \multicolumn{2}{|c|}{${\text { Until } 21^{\text {st }} \text { day }}$} \\
\hline & $\mathbf{Z}$ & p-level & $\mathbf{Z}$ & p-level & $\mathbf{Z}$ & p-level \\
\hline 0 & -0.832 & 0.405 & -1.661 & 0.097 & -1.265 & 0.206 \\
\hline 50 & -1.464 & 0.143 & 0.180 & 0.857 & 0.795 & 0.427 \\
\hline 100 & 0.392 & 0.695 & -0.254 & 0.800 & 0.420 & 0.675 \\
\hline 150 & 0.000 & 1.000 & 0.148 & 0.883 & 0.241 & 0.809 \\
\hline
\end{tabular}

TABLE II

Differences in colony strength parameters between honey bee colonies treated with AbM extract (100 mg/kg/day) and controls in period 2011-2013 (Mann-Whitney $U$ test).

\begin{tabular}{|c|c|c|c|c|c|c|c|}
\hline \multirow{2}{*}{$\begin{array}{c}\text { Monitoring } \\
\text { day }\end{array}$} & \multirow{2}{*}{ Colony strength parameter } & \multicolumn{2}{|c|}{2011} & \multicolumn{2}{|c|}{2012} & \multicolumn{2}{|c|}{2013} \\
\hline & & $\mathbf{Z}$ & p & $\mathbf{Z}$ & p & $\mathbf{Z}$ & p \\
\hline \multirow{5}{*}{ S1 } & OB & -1.928 & 0.054 & -0.575 & 0.565 & 0.334 & 0.738 \\
\hline & SB & -1.448 & 0.148 & -0.189 & 0.850 & 0.111 & 0.911 \\
\hline & HR & -0.381 & 0.704 & -0.384 & 0.701 & 1.319 & 0.187 \\
\hline & PR & -0.781 & 0.435 & 0.574 & 0.566 & 1.969 & 0.049 \\
\hline & $\mathrm{AB}$ & -2.046 & 0.041 & -1.189 & 0.234 & 0.467 & 0.641 \\
\hline \multirow{5}{*}{$\mathrm{S} 2$} & OB & 2.188 & 0.029 & 0.189 & 0.850 & 2.891 & 0.004 \\
\hline & SB & 2.342 & 0.019 & -1.512 & 0.131 & 2.713 & 0.007 \\
\hline & HR & 1.516 & 0.129 & -0.294 & 0.769 & 1.583 & 0.113 \\
\hline & PR & 0.297 & 0.766 & -0.189 & 0.850 & -1.821 & 0.069 \\
\hline & $\mathrm{AB}$ & 2.159 & 0.031 & 0.958 & 0.338 & 2.748 & 0.006 \\
\hline \multirow{5}{*}{ S3 } & OB & 1.375 & 0.169 & 2.652 & 0.008 & 1.599 & 0.110 \\
\hline & SB & 2.491 & 0.013 & 2.646 & 0.008 & 1.159 & 0.247 \\
\hline & HR & 2.711 & 0.007 & 2.646 & 0.008 & 1.488 & 0.137 \\
\hline & PR & -1.454 & 0.146 & 0.474 & 0.636 & 1.380 & 0.168 \\
\hline & $\mathrm{AB}$ & 2.657 & 0.008 & 1.150 & 0.250 & 2.026 & 0.043 \\
\hline
\end{tabular}

S1 - day of first spring treatment; S2 - day of second spring treatment (22 days after day S1); S3 - 22 day after the S2; OB - open brood area; SB - sealed brood area; HR - honey reserves; PR - pollen reserves, AB - adult bee population. 
Among the 15 recorded cases of significant $(\mathrm{p}<$ 0.05 or $p<0.01$ ) differences, 14 were in favour of the treated colonies. $\mathrm{AB}$ and $\mathrm{SB}$ were most frequently significantly $(\mathrm{p}<0.05$ or $\mathrm{p}<0.01)$ higher in treated colonies compared to control (in four cases), followed by OB (in three cases), HR (two cases) and PR (one case). There was only one exception (AB on the day S1 in 2011) where a significantly $(p=0.041)$ higher value was recorded in the control. Generally, brood rearing and adult population growth $(\mathrm{OB}, \mathrm{SB}$ and $\mathrm{AB})$ were more often affected by $A$. brasiliensis extract than the productive capacity (PR and HR). Significant ( $p<$ 0.05 or $p<0.01$ ) differences in favour of the treated colonies were more often recorded in 2011 (six cases) and 2013 (five cases), than in 2012 (three cases). Considering monitoring days, positive effects of $A$. brasiliensis were mainly observed in April, whereas its significant $(\mathrm{p}<0.05$ or $\mathrm{p}<0.01)$ influence was most often recorded on the day S3 (SB and HR in 2011 and 2012; AB in 2011 and 2013 and OB in 2012) and slightly less on day S2 (OB, SB and AB in both 2011 and 2013). On the day S1, only PR in 2013 was significantly (p < 0.05 ) increased by the treatment.

\section{THE INFLUENCE OF THE YEAR ON STRENGTH} PARAMETERS IN TREATED AND CONTROL HONEY BEE COLONIES

The comparisons of average values of strength parameters in the whole three-year period (KruskalWallis test) and between paired years (MannWhitney U test) suggested no consistent influence of the year on the any of monitored strength parameter either in the treated bee colonies (Table III) or the controls (Table IV).

\section{DISCUSSION}

There is great concern about the current decline in the number of managed honey bees. Factors responsible for colony losses differ from continent to continent and from region to region, so there is no globally valid solution to honey bee decline (Genersch 2010). Thus, maintaining healthy and strong honey bee colonies is of crucial importance in the prevention of colony losses in all regions

TABLE III

Differences in colony strength parameters in three consecutive years in honey bee colonies treated with AbM extract (100 $\mathrm{mg} / \mathrm{kg} / \mathrm{day})$.

\begin{tabular}{|c|c|c|c|c|c|c|c|c|c|}
\hline \multirow{3}{*}{$\begin{array}{l}\text { Monitoring } \\
\text { day }\end{array}$} & \multirow{3}{*}{$\begin{array}{c}\text { Colony } \\
\text { strength } \\
\text { parameter }\end{array}$} & \multirow{2}{*}{\multicolumn{2}{|c|}{ Kruskal-Wallis test }} & \multicolumn{6}{|c|}{ Mann-Whitney U test } \\
\hline & & & & \multicolumn{2}{|c|}{ 2011/2012 } & \multicolumn{2}{|c|}{$2011 / 2013$} & \multicolumn{2}{|c|}{$2012 / 2013$} \\
\hline & & $\mathbf{H}$ & $p(d f=2)$ & $\mathbf{z}$ & $\mathbf{p}$ & $\mathbf{z}$ & $\mathbf{p}$ & $\mathbf{z}$ & $\mathbf{p}$ \\
\hline \multirow{5}{*}{ S1 } & OB & 17.414 & $<0.001$ & -0.904 & 0.366 & -3.989 & $<0.000$ & -2.389 & 0.017 \\
\hline & SB & 2.065 & 0.356 & -0.956 & 0.339 & -1.323 & 0.186 & 0.292 & 0.770 \\
\hline & HR & 10.990 & 0.004 & 2.503 & 0.012 & -1.552 & 0.121 & -3.030 & 0.002 \\
\hline & PR & 8.276 & 0.016 & -2.710 & 0.007 & -0.290 & 0.772 & 2.604 & 0.009 \\
\hline & $\mathrm{AB}$ & 14.461 & 0.001 & -0.957 & 0.338 & -3.537 & $<0.000$ & -2.405 & 0.016 \\
\hline \multirow{5}{*}{ S2 } & OB & 4.016 & 0,134 & 1.460 & 0.144 & 1.648 & 0.099 & -0.982 & 0.326 \\
\hline & SB & 2.621 & 0.270 & 0.159 & 0.873 & 1.586 & 0.113 & 0.877 & 0.381 \\
\hline & HR & 6.831 & 0.033 & 1.590 & 0.112 & -1.702 & 0.089 & -2.254 & 0.024 \\
\hline & PR & 0.761 & 0.684 & 0.372 & 0.710 & 0.896 & 0.371 & 0.053 & 0.958 \\
\hline & $\mathrm{AB}$ & 3.642 & 0.162 & 0.841 & 0,400 & 1.981 & 0.048 & -0.136 & 0.892 \\
\hline \multirow{5}{*}{ S3 } & OB & 8.850 & 0.012 & -1.439 & 0.150 & 1.741 & 0.082 & 2.956 & 0.003 \\
\hline & SB & 15.094 & 0.001 & -1.889 & 0.059 & 2.666 & 0.008 & 3.464 & 0.001 \\
\hline & HR & 23.140 & $<0.001$ & 3.506 & $<0.000$ & 4.308 & $<0.000$ & -0.293 & 0.770 \\
\hline & PR & 6.185 & 0.045 & -2.420 & 0.016 & -0.735 & 0.463 & 1.996 & 0.046 \\
\hline & $\mathrm{AB}$ & 6.932 & 0.031 & 1.073 & 0.283 & 2.676 & 0.007 & 0.581 & 0.562 \\
\hline
\end{tabular}

S1 - day of first spring treatment; S2 - day of second spring treatment (22 days after day S1); S3 - 22 day after the S2; OB - open brood area; SB - sealed brood area; HR - honey reserves; PR - pollen reserves, AB - adult bee population. 
TABLE IV

Differences in colony strength parameters in three consecutive years in control honey bee colonies.

\begin{tabular}{|c|c|c|c|c|c|c|c|c|c|}
\hline \multirow{3}{*}{$\begin{array}{l}\text { Monitoring } \\
\text { day }\end{array}$} & \multirow{3}{*}{$\begin{array}{c}\text { Colony } \\
\text { strength } \\
\text { parameter }\end{array}$} & \multirow{2}{*}{\multicolumn{2}{|c|}{ Kruskal-Wallis test }} & \multicolumn{6}{|c|}{ Mann-Whitney U test } \\
\hline & & & & \multicolumn{2}{|c|}{ 2011/2012 } & \multicolumn{2}{|c|}{$2011 / 2013$} & \multicolumn{2}{|c|}{$2012 / 2013$} \\
\hline & & $\mathbf{H}$ & $p(d f=2)$ & $\mathbf{z}$ & $\mathbf{p}$ & $\mathbf{z}$ & $\mathbf{p}$ & $\mathbf{z}$ & $\mathbf{p}$ \\
\hline \multirow{5}{*}{ S1 } & OB & 1.192 & 0.551 & 0.577 & 0.564 & -0.866 & 0.386 & -0.866 & 0.386 \\
\hline & SB & 0.500 & 0.779 & 0.289 & 0.773 & 0.866 & 0.386 & 0.000 & 1.000 \\
\hline & HR & 4.195 & 0.123 & 2.205 & 0.027 & 0.744 & 0.457 & -0.887 & 0.375 \\
\hline & PR & 6.639 & 0.036 & -1.452 & 0.146 & 2.021 & 0.043 & 2.033 & 0.042 \\
\hline & $\mathrm{AB}$ & 0.584 & 0.747 & 0.607 & 0.544 & 0.667 & 0.505 & 0.000 & 1.000 \\
\hline \multirow{5}{*}{$\mathrm{S} 2$} & OB & 3.038 & 0.219 & 0.866 & 0.386 & 2.021 & 0.043 & 0.000 & 1.000 \\
\hline & SB & 9.582 & 0.008 & -2.309 & 0.021 & 2.178 & 0.029 & 2.309 & 0.021 \\
\hline & HR & 5.770 & 0.056 & 2.205 & 0.027 & 1.764 & 0.078 & -0.599 & 0.549 \\
\hline & PR & 1.850 & 0.397 & -0.290 & 0.772 & -1.479 & 0.139 & -0.726 & 0.468 \\
\hline & $\mathrm{AB}$ & 10.021 & 0.007 & -2.366 & 0.018 & 2.352 & 0.019 & 2.352 & 0.019 \\
\hline \multirow{5}{*}{$\mathrm{S} 3$} & OB & 1.053 & 0.591 & 0.877 & 0.381 & 0.866 & 0.386 & 0.000 & 1.000 \\
\hline & SB & 2.452 & 0.293 & -1.307 & 0.191 & -0.294 & 0.769 & 1.340 & 0.180 \\
\hline & HR & 9.582 & 0.008 & 2.309 & 0.021 & 2.309 & 0.021 & -2.178 & 0.029 \\
\hline & PR & 9.615 & 0.008 & -2.309 & 0.021 & 2.191 & 0.028 & 2.323 & 0.020 \\
\hline & $\mathrm{AB}$ & 8.355 & 0.015 & -2.381 & 0.017 & 0.833 & 0.405 & 2.428 & 0.015 \\
\hline
\end{tabular}

S1 - day of first spring treatment; S2 - day of second spring treatment (22 days after day S1); S3 - 22 day after the S2; OB - open brood area; SB - sealed brood area; HR - honey reserves; PR - pollen reserves, AB - adult bee population.

of the world, and natural-based treatments which may enhance colony strength or stimulate bee defence are more than welcome (Stevanovic et al. 2012). Thus, this study was done to investigate if supplementation with $A$. brasiliensis extract could enhance bee colony strength and help to prevent their mortality. As this is the first trial of A. brasiliensis extract treatment of bees, it was necessary to evaluate if it is safe for the bees and to decide on the appropriate dose and feeding mode. The results of our laboratory experiment showed that the extract is safe for the bees in each applied dose, which consequently enabled the field trial. Although in laboratory conditions the survival of bees did not depend on feeding mode, only syrup was fully consumed and ensured the complete intake of the extract. In contrast, the other feeding mode, candy, appeared inappropriate because it desiccated so the bees could not intake the whole quantity of the test substance. These results are in accordance with previous reports on these two feeding modes (Costa et al. 2010, Higes et al. 2011).

Adequate nutrition is essential for the normal growth and development of honey bee colonies and ensures maintaining colonies in good condition. Continuous availability of pollen insures the growth of colonies, provides protein to adult bees and stimulates brood rearing (DeGrandi-Hoffman et al. 2008, 2010). Protein content in both larval and adult diet positively influences worker longevity (Li et al. 2014), but best survival is achieved when workers are fed with both pollen and royal jelly (Wang et al. 2014). Pollen availability during the larval development directly affects the reproductive quality of drones (Czekońska et al. 2015).

Inadequate nutrition may contribute to colony losses, as colonies with low nutritional reserves have reduced brood rearing (Mattila and Otis 2007, DeGrandi-Hoffman et al. 2008). Since colony nutrition can be effectively managed, several studies tested the beneficial influence of food supplements on honey bees. Pollen, pollensubstitute diets (protein supplements) and protein/ vitamin supplements were most evaluated (Nabors 2000, Mattila and Otis 2006, DeGrandi-Hoffman et al. 2008, Pajuelo et al. 2008). Supplemental feeding with pollen or substitutes during seasonal pollen shortages may enhance brood rearing (Nabors 
2000, Mattila and Otis 2006), so it was accepted as a routine in beekeeping practice. Interestingly, comparing to natural pollen cake, pollen substitute patty (containing $16.5 \%$ protein and $66 \%$ carbohydrate and no natural pollen) exerted significantly greater effects in stimulating brood rearing and adult population growth (DeGrandiHoffman et al. 2008). However, no significant influence on brood and colony development, winter survival and productive capacity (pollen and honey reserves) was caused by protein/vitamin supplementation in the study of Pajuelo et al. (2008). A. brasiliensis extract supplementation in the field experiment of this study caused significant increase of colony strength parameters, with brood rearing and adult population growth $(\mathrm{OB}$, $\mathrm{SB}$ and $\mathrm{AB}$ ) being more often affected than honey and pollen reserves (HR and PR). These findings are in some extent comparable with the effects of pollen substitutes (DeGrandi-Hoffman et al. 2008), although our study lasted much longer (three years) than the study of DeGrandi-Hoffman et al. (2008) and was performed with different treatment strategies. A. brasiliensis extract was more powerful in enhancing colony strength than pollen supplements in the study of Mattila and Otis (2006) and protein/vitamin supplements in the study of Pajuelo et al. (2008).

In our study, no consistency in year influence could be identified, although the study lasted three consecutive years which differed in weather conditions. Contrary to temperate winters 2010/2011 and 2012/2013, the winter 2011/2012 was unfavourable for the bees (mild December 2011 and January 2012 and an extremely cold period during a whole week in February 2012). This may have somehow influenced strength parameters $\mathrm{OB}, \mathrm{SB}, \mathrm{AB}$ and $\mathrm{PR}$ recorded to have higher variability at the beginning of April 2012 (on the day S2). Besides, positive influence of the test substance was lowest in 2012, being observed only at the end of April. Such results might result from highly variable and unfavourable weather conditions in late winter. Thus, the negative effects of the extremely cold period in February 2012 were not compensated with $A$. brasiliensis extract treatment before the end of April. Better results were observed in years with optimal winter and spring climatic conditions (2011 and 2013) when as early as first spring $A$. brasiliensis extract treatment positively influenced brood rearing and adult population growth $(\mathrm{OB}, \mathrm{SB}$ and $\mathrm{AB})$ at the beginning of April (on the day S2). However, on day S3 (the end of April) three strength parameters, including honey yield, were significantly higher in the treated colonies in 2011 and 2012 (favourable and unfavourable climate, respectively), and only $\mathrm{AB}$ in 2013 (favourable conditions). This is another evidence that the effect of $A$. brasiliensis extract was not consistently influenced by weather, contrary to pollen supplementation (Mattila and Otis 2006), which enhanced honey yield only when spring foraging had been heavily reduced by unfavourable weather condition.

Positive effects of $A$. brasiliensis extract in this study were mainly observed in April indicating the benefit of both spring treatments. In contrast, autumn treatment has not proved helpful, except in the third year of the experiment, when a slightly positive effect was recorded following the first spring treatment. Whether higher doses of $A$. brasiliensis extract in autumn treatment may express a better stimulative effect remains to be investigated in the future.

In conclusion, $A$. brasiliensis extract is safe for the bees and helps maintaining strong colonies when supplemented at a dose of $100 \mathrm{mg} / \mathrm{kg} /$ day, especially in spring. Brood rearing and adult population growth are more susceptible than productive capacity (honey and pollen reserves) to its positive influence in spring. Before we recommend $A$. brasiliensis extract for routine use in beekeeping, it may be worth testing higher doses, particularly in autumn, in order to achieve 
higher efficiency noticeable during the first spring treatment. Finally, further research is necessary to reveal the mechanisms underlying the effect of $A$. brasiliensis extract on honey bees.

\section{ACKNOWLEDGMENTS}

This research was supported by the Ministry of Education, Science and Technological Development of the Republic of Serbia (Grant No. III46002), led by professor Zoran Stanimirovic.

\section{REFERENCES}

ALVAREZ-SUAREZ JM, TULIPANI S, ROMANDINI S, BERTOLI E AND BATTINO M. 2010. Contribution of honey in nutrition and human health: a review. Mediterr J Nutr Metab 3: 15-23.

BOGDANOV S. 2006. Contaminants of bee products. Apidologie 37: 1-18.

COSTA C, LODESANI M AND MAISTRELLO L. 2010. Effect of thymol and resveratrol administered with candy or syrup on the development of Nosema ceranae and on the longevity of honeybees (Apis mellifera L.) in laboratory conditions. Apidologie 41: 141-150.

CZEKOŃSKA K, CHUDA-MICKIEWICZ B AND SAMBORSKI J. 2015. Quality of honeybee drones reared in colonies with limited and unlimited access to pollen. Apidologie 46: 1-9.

DEGRANDI-HOFFMAN G, CHEN Y, HUANG E AND HUANG MH. 2010. The effect of diet on protein concentration, hypopharyngeal gland development and virus load in worker honey bees (Apis mellifera L.). J Insect Physiol 56: 1184-1191.

DEGRANDI-HOFFMAN G, WARDELL G, AHUMADASEGURA F, RINDERER T, DANKA R AND PETTIS J. 2008. Comparisons of pollen substitute diets for honey bees: consumption rates by colonies and effects on brood and adult populations. J Apicult Res 47: 265-270.

DE LA RÚA P, JAFFÉ R, DALL'OLIO R, MUÑOZ I AND SERRANO J. 2009. Biodiversity, conservation and current threats to European honeybees. Apidologie 40: 263-284.

DELAPLANE KS, VAN DER STEEN J AND GUZMANNOVOA E. 2013. Standard methods for estimating strength parameters of Apis mellifera colonies. In: Dietemann V, Ellis JD and Neumann P (Eds), The Coloss Beebook, Volume I: Standard methods for Apis mellifera research. J Apicult Res 52.

ELLIS JD, EVANS JD AND PETTIS JS. 2010. Colony losses, managed colony population decline and colony collapse disorder in the United States. J Apicult Res 49: 134-136.

EVANS JD, CHEN YP, DI PRISCO G, PETTIS J AND WILLIAMS V. 2009. Bee cups: single-use cages for honey bee experiments. J Apicult Res 48: 300-302.

FRIES I. 1988. Infectivity and multiplication of Nosema apis Z. in the ventriculus of the honey bee. Apidologie 19: 319328.

GENERSCH E. 2010. Honey bee pathology: current threats to honey bees and beekeeping. Appl Microbiol Biot 87: 87-97.

GENERSCH E ET AL. 2010. The German bee monitoring project: a long term study to understand periodically high winter losses of honey bee colonies. Apidologie 41: 332352.

GUTERRES ZR, MANTOVANI MS, EIRA AF, RIBEIRO LR AND JORDÃO BQ. 2005. Genotoxic and antigenotoxic effects of organic extracts of mushroom Agaricus blazei Murrill on V79 cells. Genet Mol Biol 28: 458-463.

HETLAND G, JOHNSON E, LYBERG T, BERNARDSHAW S, TRYGGESTAD AM AND GRINDE B. 2008. Effects of the medicinal mushroom Agaricus blazei Murill on immunity, infection and cancer. Scand J Immunol 68: 363-370.

HIGES M, NOZAL MJ, ÁlVARO A, BARRIOS L, MEANA A, MARTÍN-HERNÁNDEZ R, BERNAL JL AND BERNAL J. 2011. The stability and effectiveness of fumagillin in controlling Nosema ceranae (Microsporidia) infection in honey bees (Apis mellifera) under laboratory and field conditions. Apidologie 42: 364-377.

ISHII PL, PRADO CK, MAURO MO, CARREIRA CM, MANTOVANI MS, RIBEIRO LR, DICHI JB AND OLIVEIRA RJ. 2011. Evaluation of Agaricus blazei in vivo for antigenotoxic, anticarcinogenic, phagocytic and immunomodulatory activities. Regul Toxicol Pharm 59: 412-422.

JOHNSON E, FØRLAND DT, SAETRE L, BERNARDSHAW SV, LYBERG T AND HETLAND G. 2009. Effect of an extract based on the medicinal mushroom Agaricus blazei Murill on release of cytokines, chemokines and leukocyte growth factors in human blood ex vivo and in vivo. Scand J Immunol 69: 242-250.

KIM CF, JIANG JJ, LEUNG KN, FUNG KP AND LAU CB. 2009. Inhibitory effects of Agaricus blazei extracts on human myeloid leukemia cells. J Ethnopharmacol 122: 320-326.

KOZARSKI M, KLAUS A, JAKOVLJEVIC D, TODOROVIC N, NIKSIC M, VRVIC MM AND VAN GRIENSVEN LJLD. 2014. Dietary polysaccharide extracts of Agaricus brasiliensis fruiting bodies: chemical characterization and bioactivities at different levels of purification. Food Res Int 64: 53-64. 
KOZARSKI M, KLAUS A, NIKSIC M, JAKOVLJEVIC D, HELSPER JPFG AND VAN GRIENSVEN LJLD. 2011. Antioxidative and immunomodulating activities of polysaccharide extracts of the medicinal mushrooms Agaricus bisporus, Agaricus brasiliensis, Ganoderma lucidum and Phellinus linteus. Food Chem 129: 16671675.

KOZMUS P, STEVANOVIC J, STANIMIROVIC Z, STOJIC V, KULISIC Z AND MEGLIC V. 2007. Analysis of mitochondrial DNA in honey bees (Apis mellifera) from Serbia. Acta Vet 57: 465-476.

LE CONTE Y, ELLIS M AND RITTER W. 2010. Varroa mites and honey bee health: can Varroa explain part of the colony losses? Apidologie 41: 353-363.

LI C, XU B, WANG Y, YANG Z AND YANG W. 2014. Protein content in larval diet affects adult longevity and antioxidant gene expression in honey bee workers. Entomol Exp Appl 151: 19-26.

LOUCIF-AYAD W, ARIBI N AND SOLTANI N. 2008. Evaluation of secondary effects of some acaricides on Apis mellifera intermissa (Hymenoptera, Apidae): acetylcholinesterase and glutathione S-transferase activities. Eur J Sci Res 21: 642-649.

MAISTRELLO L, LODESANI M, COSTA C, LEONARDI F, MARANI G, CALDON M, MUTINELLI F AND GRANATO A. 2008. Screening of natural compounds for the control of nosema disease in honey bees (Apis mellifera). Apidologie 39: 436-445.

MANTOVANI MS, BELLINI MF, ANGELI JP, OLIVEIRA RJ, SILVA AF AND RIBEIRO LR. 2008. $\beta$-Glucans in promoting health: prevention against mutation and cancer. Mutat Res-Rev Mutat 658: 154-161.

MARQUES DE SÁ JP. 2007. Applied statistics using SPSS, STATISTICA, MATLAB and $R, 2^{\text {nd }}$ ed., Heidelberg: Springer, $495 \mathrm{p}$.

MATTILA HR AND OTIS GW. 2006. Influence of pollen diet in spring on development of honey bee (Hymenoptera: Apidae) colonies. J Econ Entomol 99: 604-613.

MATTILA HR AND OTIS GW. 2007. Dwindling pollen resources trigger the transition to broodless populations of long-lived honeybees each autumn. Ecol Entomol 32: 496-505.

MORITZ RFA, DE MIRANDA J, FRIES I, LE CONTE Y, NEUMANN P AND PAXTON R. 2010. Research strategies to improve honeybee health in Europe. Apidologie 41: 227-242.

MUÑOZ I, STEVANOVIC J, STANIMIROVIC Z AND DE LA RÚA P. 2012. Genetic variation of Apis mellifera from Serbia inferred from mitochondrial analysis. J Apic Sci 56: 59-69.

NABORS R. 2000. The effects of spring feeding pollen substitute to colonies of Apis mellifera. Am Bee J 140: 322-323.
NEUMANN P AND CARRECK NL. 2010. Honey bee colony losses. J Apicult Res 49: 1-6.

OIE - Office International Des Epizooties. 2013. Manual of Diagnostic Tests and Vaccines for Terrestrial Animals 2013. Available at: http://www.oie.int/en/internationalstandard-setting/terrestrial-manual/access-online/. Accessed on March 5, 2015.

PAJUELO AG, TORRES C AND BERMEJO FJO. 2008. Colony losses: A double blind trial on the influence of supplementary protein nutrition and preventative treatment with fumagillin against Nosema ceranae. J Apicult Res 47: 84-86.

PETTIS JS, COLLINS AM, WILBANKS R AND FELDLAUFER MF. 2004a. Effects of coumaphos on queen rearing in the honey bee Apis mellifera. Apidologie 35: 605-610.

PETTIS JS, KOCHANSKY JP AND FELDLAUFER MF. 2004b. Larval Apis mellifera L. (Hymenoptera, Apidae) mortality after topical application of antibiotics and dusts. J Econ Entomol 97: 171-176.

POTTS SG, ROBERTS SPM, DEAN R, MARRIS G, BROWN M, JONES R AND SETTELE J. 2010. Declines of managed honey bees and beekeepers in Europe. J Apicult Res 49: 15-22.

RADAKOVIC M, STEVANOVIC J, DJELIC N, LAKIC N, KNEZEVIC-VUKCEVIC J, VUKOVIC-GACIC B AND STANIMIROVIC Z. 2013. Evaluation of the DNA damaging effects of amitraz on human lymphocytes in the Comet assay. J Biosciences 38: 53-62.

RHMZ - Republic Hydrometeorological Sevice of Serbia. 2013. Available at: http://www.hidmet.gov.rs/index_eng. php. Accessed on March 5, 2015.

ROUPAS P, KEOGH J, NOAKES M, MARGETTS C AND TAYLOR P. 2012. The role of edible mushrooms in health: Evaluation of the evidence. J Funct Foods 4: 687-709.

SAVIĆ T, PATENKOVIĆ A, SOKOVIĆ M, GLAMOČLIJA J, ANDJELKOVIĆ M AND VAN GRIENSVEN LJLD. 2011. The effect of royal sun agaricus, Agaricus brasiliensis S. Wasser et al., extract on methyl methanesulfonate caused genotoxicity in Drosophila melanogaster. Int J Med Mushrooms 13: 377-385.

SMIDERLE FR, ALQUINI G, TADRA-SFEIR MZ, IACOMINI M, WICHERS HJ AND VAN GRIENSVEN LJLD. 2013. Agaricus bisporus and Agaricus brasiliensis $(1 \rightarrow 6) \beta$-D-glucans show immunostimulatory activity on human THP-1 derived macrophages. Carbohyd Polym 94: 91-99.

SMIDERLE FR, RUTHES AC, VAN ARKEL J, CHANPUT W, IACOMINI M, WICHERS HJ AND VAN GRIENSVEN LJLD. 2011. Polysaccharides from Agaricus bisporus and Agaricus brasiliensis show similarities in their structures and their immunomodulatory 
effects on human monocytic THP-1 cells. BMC Complem Altern M 11: 58.

STANIMIROVIC Z, STEVANOVIC J, BAJIC V AND RADOVIC I. 2007. Evaluation of genotoxic effects of fumagillin by cytogenetic tests in vivo. Mutat Res Gen Tox En 628: 1-10.

STANIMIROVIC Z, STEVANOVIC J, JOVANOVIC S AND ANDJELKOVIC M. 2005. Evaluation of genotoxic effects of Apitol ${ }^{\circledR}$ (cymiazole hydrochloride) in vitro by measurement of sister chromatid exchange. Mutat Res Gen Tox En 588: 152-157.

STEVANOVIC J, STANIMIROVIC Z, LAKIC N, DJELIC N AND RADOVIC I. 2012. Stimulating effect of sugar dusting on honey bee grooming behaviour. Entomol Exp Appl 143: 23-30.

STEVANOVIC J, STANIMIROVIC Z, RADAKOVIC $M$ AND STOJIC V. 2008. In vitro evaluation of the clastogenicity of fumagillin. Environ Mol Mutagen 49: 594-601.
VANENGELSDORP D ET AL. 2009. Colony collapse disorder: a descriptive study. PLoS ONE 4: e6481.

VIUDA-MARTOS M, RUIZ-NAVAJAS Y, FERNÁNDEZLÓPEZ J AND PÉREZ-ÁLVAREZ JA. 2008. Functional properties of honey, propolis, and royal jelly. J Food Sci 73: R117-R124.

WANG H, ZHANG SW, ZENG ZJ AND YAN WY. 2014. Nutrition affects longevity and gene expression in honey bee (Apis mellifera) workers. Apidologie 45: 618-625.

WASSER S, DIDUKH MY, AMAZONAS MAL, NEVO E, STAMETS P AND EIRA AF. 2002. Is a widely cultivated culinary-medicinal Royal Sun Agaricus (the Himematsutake mushroom) indeed Agaricus blazei Murill? Int J Med Mushrooms 4: 267-290.

WASSER S AND WEIS A. 1999. Medicinal properties of substances occurring mushrooms. Int J Med Mushrooms 1: 31-62.

WEI S AND VAN GRIENSVEN LJLD. 2008. Pro- and antioxidative properties of medicinal mushroom extracts. Int J Med Mushrooms 10: 315-324. 